\title{
Tree community dynamics in a forest adjacent to the reservoir of a hydroelectric power plant in the southern Brazilian Atlantic Forest
}

\author{
Dinámica de la comunidad de árboles en un bosque adyacente al reservorio \\ de una central hidroeléctrica en la Mata Atlántica del sur de Brasil
}

\author{
Bruna Danieli Fuck Valim a , Manoela Bez Vefago a, Edilaine Duarte a, Aline Gross a, \\ Guilherme Neto dos Santos a, Janaina Gabriela Larsen a, Tarik Cuchi a, Jéssica Thalheimer de Aguiar a, \\ Jaqueline Beatriz Brixner Dreyer a, Ana Carolina da Silva a , Pedro Higuchi a* \\ * Corresponding author: ${ }^{a}$ Universidade do Estado de Santa Catarina, Departamento de Engenharia Florestal, \\ Av. Luiz de Camões, 2090, Lages, Brasil, phone: 55-49-32899308, higuchip@gmail.com
}

\section{SUMMARY}

\begin{abstract}
This study aimed at analyzing the dynamics of tree components in a forest adjacent to the Barra Grande Hydroelectric Power Plant reservoir, in the southern Brazilian Atlantic Forest, located in the municipality of Capão Alto. In 2013, this area was previously inventoried and divided into three sectors according to the distance from the reservoir: lower sector (in contact with the reservoir), intermediate sector (a slope area following the first sector) and upper sector (near the slope top). Fifty plots were allocated in the sectors, where all tree individuals with DBH (diameter at breast height) higher than or equal to $5 \mathrm{~cm}$ were inventoried (identified and measured at the circumference). In 2017 the surviving individuals were measured again, the dead ones were registered and the recruits (those with DBH reaching $5 \mathrm{~cm}$ ) were included into the survey. Dynamics rates in number of individuals and basal area were calculated. The tree community under study has shown species richness stability, though also structural development, which is typical of areas that are facing a self-thinning process. The higher density populations of each sector have shown a similar structural dynamics pattern. There were no differences in the demographic rates among sectors, indicating that, approximately 12 years after the reservoir filling, the forest dynamics has not been influenced by the reservoir but by ecological factors dependent on density, such as competition.
\end{abstract}

Key words: tree growth; forest dynamics; hydroelectric power plant impact.

\section{RESUMEN}

El objetivo del estudio fue analizar la dinámica del componente arbóreo en un bosque adyacente al reservorio de la Usina Hidroeléctrica (UHE) Barra Grande en Capão Alto, Mata Atlántica del sur de Brasil. En el año 2013, se hizo un inventario en el área, y se dividió en tres sitios con diferentes distancias del embalse: sector inferior, en contacto con el embalse; sector intermedio, área de ladera tras el primer sector, y sector superior, cerca de la cima. Fueron espaciadas 50 parcelas en los sitios, donde todos los individuos arbóreos con clase diamétrica (DAP) igual o mayor a $5 \mathrm{~cm}$ fueron inventariados (se identificaron y se midieron sus circunferencias). En 2017, los individuos sobrevivientes fueron remedidos, los individuos muertos registrados, y los de reclutamiento (aquellos que alcanzaron $5 \mathrm{~cm}$ de DAP), agregados al estudio. Se calcularon las tasas de dinámica en número de individuos y en área basal. La comunidad presentó estabilidad en la riqueza de especies y desarrollo estructural, típico de áreas que se encuentran en proceso de autorraleo. Las poblaciones de mayor densidad y de cada sector presentaron patrón de dinámica estructural similar. No se observaron diferencias en las tasas demográficas entre los sitios, por lo tanto, se concluye que, aproximadamente 12 años después del llenado del embalse, el mismo no está influenciando la dinámica del bosque adyacente, siendo esta más influenciada por factores ecológicos dependientes de la densidad, como la competencia.

Palabras clave: crecimiento de árboles; dinámica de árboles; impacto de central hidroeléctrica.

\section{INTRODUCTION}

The Atlantic Forest is considered one of the Brazilian most threatened biomes, being among the 34 world hotspots due to its high degree of endemism and high number of endangered species (SOS Mata Atlântica 2012). In the state of Santa Catarina, located in the south of Brazil and inserted in the domain of the Atlantic Forest biome, there is a predominance of three forest typologies (IBGE 2012): Dense Ombrophilous Forest, found in the eastern slope areas of Serra do Mar; Mixed Ombrophilous Forest, distributed by the western plateaus of Serra do Mar; and Seasonal Forests, going from the Uruguai River basin to its tributaries, where an ecotone area is formed along with the Mixed Ombrophilous Forest. 
The Mixed Ombrophilous Forest, also known as Araucaria Forest, currently accounts for only $24.4 \%$ of its original area in the state, distributed in secondary forests of intermediary and advanced successional stages (Vibrans et al. 2013). Intense logging, mainly of the Brazilian pine tree, and the replacement of the Araucaria Forest vegetation by agriculture, grazing and silviculture areas have resulted in its forest fragmentation (Medeiros et al. 2005). Seasonal Forests have also been intensively explored in the last century (Ruschel et al. 2003); with their landscape modified and area reduced to $16 \%$ of the original size (Vibrans et al. 2013). Today, more than half of the Seasonal Forests fragments are smaller than 50 ha, being the continuous fragments with more than 200 ha extremely rare (Gasper et al. 2013, Vibrans et al. 2013).

The Upper Uruguai region is characterized as an ecological stress zone as the remnants of Seasonal Forests and Mixed Ombrophilous Forest formations meet (Souza et al. 2015). Recently, the construction of hydroelectric power plants has either replaced these remnants with lakes and dams or subjected species to a stress condition due to a recent soil waterlogging. Such developments lead to a critical situation regarding the conservation of the communities inserted in these formations, besides affecting tree floristic-structural composition over time (Lima 2016).

Studies on the dynamics of forest fragments enable to monitor and predict the transformation processes of populations and communities, therefore providing subsidies for both management and conservation (Higuchi et al. 2008). By considering that distinct typologies or communities may respond differently to the effects of reservoir filling, analyses are needed to understand the impacts of such conditions on the vegetation of transition areas between Mixed Ombrophilous Forest and Seasonal Forests (Lima 2016). The goal of this study was to analyze tree component dynamics in a forest adjacent to the Barra Grande Hydroelectric Power Plant reservoir, located in Capão Alto, SC, southern Brazilian Atlantic Forest, approximately 12 years after the reservoir filling. It was expected to detect the influence of the reservoir formation on the tree community.

\section{METHODS}

The area under study is located at latitude $28^{\circ} 11^{\prime} 45^{\prime \prime} \mathrm{S}$ and longitude $50^{\circ} 45^{\prime} 4^{\prime \prime} \mathrm{W}$, on the banks of the Barra Grande Hydroelectric Power Plant reservoir, in a forest fragment in the municipality of Capão Alto, SC, southern Brazilian Atlantic Forest, reaching approximately $700 \mathrm{~m}$ altitude. The Barra Grande Hydroelectric Power Plant was built approximately 12 years ago on the Pelotas River bed, which borders the states of Rio Grande do Sul and Santa Catarina and forms the Uruguai River Basin. The fragment under study belongs to a private property and does not show signs of intense logging or cattle presence - probably due to its steep topography (Souza et al. 2015) -, thus characterizing an advanced successional stage fragment.
The remnant under study is classified as a transition area between the Mixed Ombrophilous Forest and the Seasonal Forest (IBGE 2012). According to Köppen's classification, it has a Cfa climate, a mean annual temperature of $15.7^{\circ} \mathrm{C}$ and a mean annual rainfall from 1,200 to $1,900 \mathrm{~mm}$. It has a strongly-wavy relief and entisols and inceptisols as predominant soils (Souza et al. 2015).

Souza et al. (2015) inventoried the area in 2013 and divided it into three sectors based on terrain characteristics, along a toposequence according with the distance from the reservoir: the lower sector (average altitude $=646 \mathrm{~m}$ ), which was in contact with the reservoir and therefore in a more humid area; the intermediate sector (average altitude $=711 \mathrm{~m}$ ), which was located in the slope area following the first sector; and the upper sector (average altitude $=732 \mathrm{~m}$ ), which was located near the top of the slope (figure 1). Permanent plots of $10 \times 20 \mathrm{~m}\left(200 \mathrm{~m}^{2}\right)$ were allocated in each sector and systematically distributed $5 \mathrm{~m}$ from each other, making 1 ha of sampled area. Fifteen plots were installed in the lower sector, 20 in the intermediate sector and 15 in the upper sector, where all tree individuals with DBH - diameter at breast height - higher than or equal to $5 \mathrm{~cm}$ were inventoried (identified, tagged and measured at circumference). The intermediate sector had a superior number of plots because this part of the terrain was larger than the others. Multiple stems individuals were inventoried when the DBH squares sum root was equal to or higher than $5 \mathrm{~cm}$.

The community was inventoried for the second time in 2017 (four years after the first measurements) and surviving individuals were then remeasured while dead individuals were registered and recruits (DBH equal to $5 \mathrm{~cm}$ ) included in the survey, tagged and identified. Identifications were carried out by comparisons with literature and specialists. Species were distributed in families according to the APG IV system (APG IV 2016).

Mortality rate (MR), recruitment rate (RR), both gain (GR) and loss (LR) rates in basal area (Lieberman et al. 1985, Primack et al. 1985, Sheil and May 1996) and the net change in the number of individuals (NCNI) and basal area rates (NCBA) (Korning and Balslev 1994) were calculated for the community as a whole, for each population, for each sector community and for the 10 highest density populations by sector, through equations [1], [2], [3], [4], [5] and [6] (all results in \% year ${ }^{-1}$ ):

$$
\begin{gathered}
\mathrm{MR}=\left(1-\left(\left(\mathrm{N}_{0}-\mathrm{d}\right) / \mathrm{N}_{0}\right)^{1 / t}\right) \times 100 \\
\mathrm{RR}=\left(1-\left(1-\mathrm{r} / \mathrm{N}_{1}\right)^{1 / t}\right) \times 100 \\
\mathrm{LR}=\left(1-\left(\left(\mathrm{AB}_{0}-\left(\mathrm{BA}_{\mathrm{d}}+\mathrm{L}_{\text {sur }}\right)\right) / \mathrm{BA}_{0}\right)^{1 / t}\right) \times 100 \\
\mathrm{GR}=\left(1-\left(1-\left(\mathrm{BA}_{\mathrm{r}}+\mathrm{G}_{\mathrm{sur}}\right) / \mathrm{BA}_{1}\right)^{1 / \mathrm{t}}\right) \times 100 \\
\mathrm{NC}_{\mathrm{NI}}=\left[\left(\mathrm{N}_{0} / \mathrm{N}_{1}\right)^{1 / \mathrm{t}}-1\right] \times 100 \\
\mathrm{NC}_{\mathrm{BA}}=\left[\left(\mathrm{BA}_{0} / \mathrm{BA}_{1}\right)^{1 / \mathrm{t}}-1\right) \times 100
\end{gathered}
$$


Where, $\mathrm{N}_{0}=$ number of initial individuals; $\mathrm{N}_{1}=$ number of final individuals; $d=$ number of dead individuals; $r=$ number of recruited individuals; $\mathrm{t}=$ time between the two inventories; $\mathrm{BA}_{0}=$ initial basal area; $\mathrm{BA}_{1}=$ final basal area; $\mathrm{BA}_{\mathrm{d}}=$ basal area of dead individuals; $\mathrm{BA}_{\mathrm{r}}=$ basal area of recruited individuals; $\mathrm{L}_{\text {sur }}=$ basal area loss of survivors; $\mathrm{G}_{\text {sur }}=$ basal area gain of survivors.

The analysis of variance (ANOVA) (parametric test) was carried out to compare the demographic rates of the number of individuals and of the basal area among sectors when data distribution was normal; in the case of non-normal distribution, the Kruskal-Wallis test (non-parametric) was performed. Data normality was verified through the Shapiro-Wilk test. If significant differences were found, analyzes were followed by the Tukey test -for normal distribution- and by the nonparametric multiple comparison test-for non-normal distribution. To compare the differen- ces in the number of individuals and basal area of the most abundant populations between 2013 and 2017, the t-test (parametric, for normal distribution) and the Mann-Whitney test (non-parametric, for non-normal distribution) were performed. To verify data normality, Shapiro-Wilk tests were also performed.

All analyzes were carried out by using the $\mathrm{R}$ statistical programming language (R Development Core Team 2017) through the forest.din function (Higuchi 2017) -for determining the demographic rates- and the package pgirmess (Giraudoux 2017).

\section{RESULTS}

Considering the community, a stability in richness with the reduction of only one species, Scutia buxifolia Reissek - going from 63 to 62 species - was observed from 2013 to 2017 (table 1). However, the structural changes

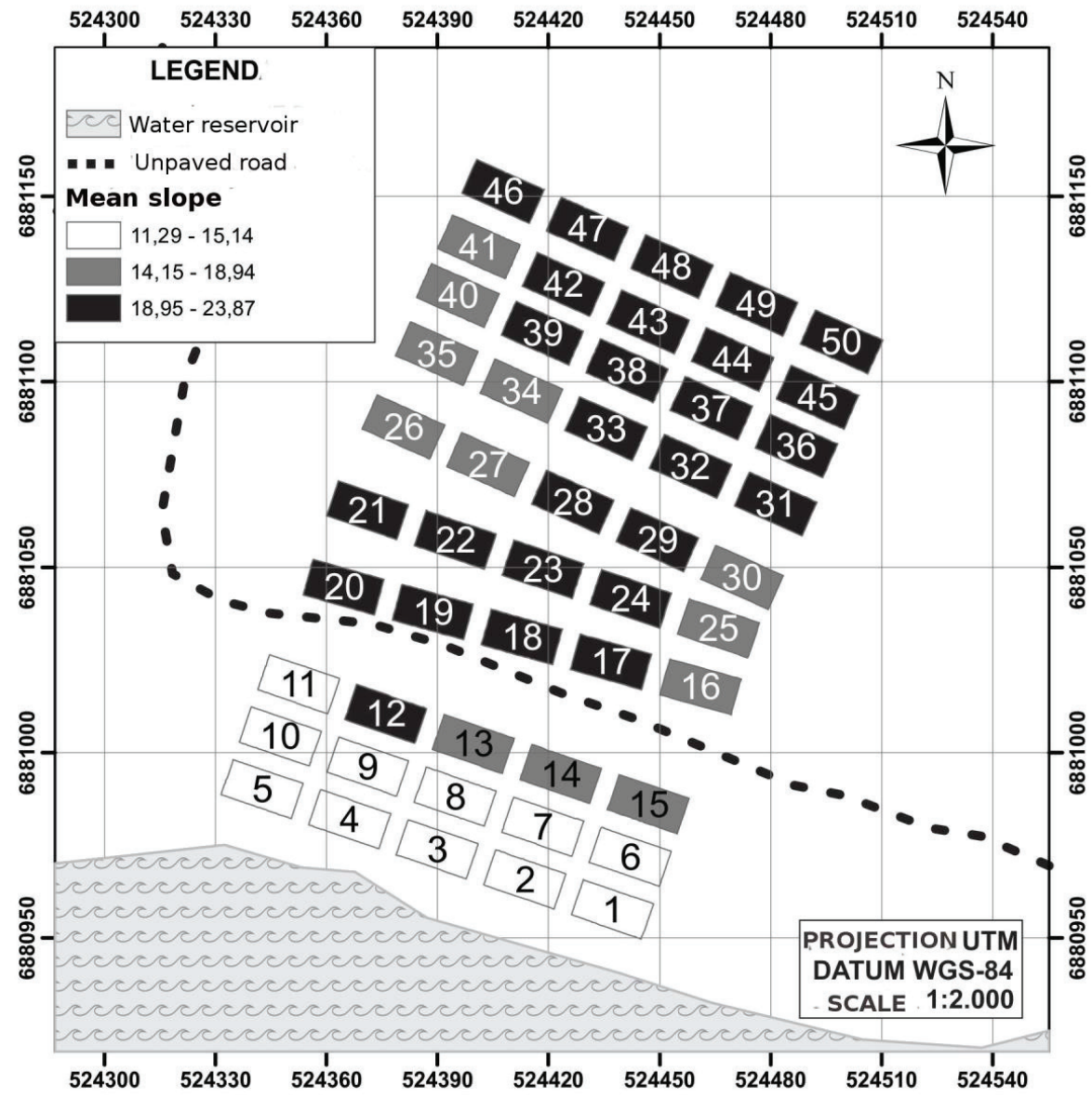

Figure 1. Sampling units location along a toposequence according with the distance from the reservoir in the municipality of Campos Novos, Southern Brazil. Plots from 1 to 15 are in low sector, from 16 to 35 are in intermediate sector and from 36 to 50 are in the upper sector (Adapted from Souza et al. 2015).

Ubicación de las unidades muestrales a lo largo de una toposecuencia de acuerdo con la distancia desde el embalse en el municipio de Campos Novos, sur de Brasil. Las parcelas de 1 a 15 se encuentran en el sector bajo, de 16 a 35 en el sector intermedio y de 36 a 50 en el sector superior (adaptado de Souza et al. 2015). 
Table 1. Initial $\left(\mathrm{N}_{0}\right)$ and final $\left(\mathrm{N}_{1}\right)$ number of individuals, initial $\left(\mathrm{BA}_{0}\right)$ and final $\left(\mathrm{BA}_{1}\right)$ basal area, mortality rate $(\mathrm{MR})$, recruitment rate (RR), basal area loss (LR) and gain (GR) and net change in the number of individuals $\left(\mathrm{NC}_{\mathrm{NI}}\right)$ and in basal area $\left(\mathrm{NC}_{\mathrm{BA}}\right)$ for populations of a forest adjacent to the reservoir of a hydroelectric plant in the southern Brazilian Atlantic Forest. All rates are in $\%$ year-1 and the basal area values are expressed in $\mathrm{m}^{2} \mathrm{ha}^{-1}$.

Número de individuos inicial $\left(\mathrm{N}_{0}\right)$ y final $\left(\mathrm{N}_{1}\right)$, área basal inicial $\left(\mathrm{BA}_{0}\right)$ y final $\left(\mathrm{BA}_{1}\right)$, tasas de mortalidad $(\mathrm{MR})$, reclutamiento $(\mathrm{RR})$, pérdida (LR) y ganancia $(\mathrm{GR})$ en área basal y cambios líquidos en el número de individuos $\left(\mathrm{NC}_{\mathrm{NI}}\right)$ y en el área basal $\left(\mathrm{NC}_{\mathrm{BA}}\right)$ para poblaciones en un bosque adyacente al embalse de una central hidroeléctrica en la Mata Atlántica del sur de Brasil. Todas las tasas están en $\%$ año ${ }^{-1}$ y los valores de área basal están representados en $\mathrm{m}^{2} \mathrm{ha}^{-1}$.

\begin{tabular}{|c|c|c|c|c|c|c|c|c|c|c|}
\hline Species & $\mathrm{N}_{0}$ & $\mathrm{~N}_{1}$ & MR & RR & $\mathrm{NC}_{\mathrm{NI}}$ & $\mathrm{BA}_{0}$ & $\mathrm{BA}_{1}$ & LR & GR & $\mathrm{NC}_{\mathrm{BA}}$ \\
\hline Aegiphila brachiata Vell. & 2 & 2 & 0 & 0 & 0 & 0.0354 & 0.0368 & 0 & 0.94 & 0.95 \\
\hline $\begin{array}{l}\text { Allophylus edulis (A.St.-Hil., Cambess. } \\
\text { et A. Juss.) Radlk. }\end{array}$ & 66 & 64 & 1.16 & 0.39 & -0.77 & 0.9646 & 1.0435 & 0.90 & 2.83 & 1.99 \\
\hline Allophylus guaraniticus (A. St.-Hil.) Radlk. & 1 & 1 & 0 & 0 & 0 & 0.0045 & 0.0083 & 0 & 14.18 & 16.52 \\
\hline Annona rugulosa (Schltdl.) H. Rainer & 13 & 12 & 1.98 & 0 & -1.98 & 0.1285 & 0.1251 & 3.74 & 3.10 & -0.67 \\
\hline Araucaria angustifolia (Bertol.) Kuntze & 2 & 1 & 15.91 & 0 & -15.91 & 0.0110 & 0.0067 & 20.86 & 10.37 & -11.71 \\
\hline Aspidosperma australe Müll.Arg. & 4 & 4 & 0 & 0 & 0 & 0.1206 & 0.1517 & 0 & 5.58 & 5.91 \\
\hline Banara tomentosa Clos & 13 & 12 & 4.09 & 2.15 & -1.98 & 0.1475 & 0.1419 & 3.63 & 2.70 & -0.96 \\
\hline Blepharocalyx salicifolius (Kunth) O.Berg & 2 & 2 & 0 & 0 & 0 & 0.0602 & 0.0691 & 0 & 3.39 & 3.51 \\
\hline Calyptranthes concinna DC. & 1 & 1 & 0 & 0 & 0 & 0.0077 & 0.0079 & 0 & 0.48 & 0.48 \\
\hline Campomanesia xanthocarpa O.Berg & 66 & 67 & 1.16 & 1.53 & 0.38 & 1.1809 & 1.2920 & 1.02 & 3.22 & 2.27 \\
\hline Casearia decandra Jacq. & 31 & 27 & 3.39 & 0 & -3.39 & 0.2458 & 0.2597 & 1.58 & 2.92 & 1.38 \\
\hline Cedrela fissilis Vell. & 1 & 1 & 0 & 0 & 0 & 0.0430 & 0.0548 & 0 & 5.90 & 6.27 \\
\hline Cestrum intermedium Sendtn. & 2 & 2 & 0 & 0 & 0 & 0.0099 & 0.0163 & 0 & 11.74 & 13.30 \\
\hline $\begin{array}{l}\text { Chrysophyllum marginatum (Hook. et } \\
\text { Arn.) Radlk. }\end{array}$ & 1 & 1 & 0 & 0 & 0 & 0.0812 & 0.0951 & 0 & 3.88 & 4.04 \\
\hline Cinnamodendron dinisii Schwacke & 1 & 1 & 0 & 0 & 0 & 0.0030 & 0.0032 & 0 & 1.26 & 1.27 \\
\hline Citronella gongonha (Mart.) R.A.Howard & 3 & 3 & 0 & 0 & 0 & 0.0347 & 0.0371 & 0 & 1.64 & 1.66 \\
\hline Coutarea hexandra (Jacq.) K. Schum. & 2 & 1 & 15.91 & 0 & -15.91 & 0.0148 & 0.0121 & 12.55 & 8.01 & -4.93 \\
\hline Cupania vernalis Cambess. & 63 & 57 & 2.9 & 0.44 & -2.47 & 1.0184 & 1.0739 & 2.16 & 3.45 & 1.34 \\
\hline Dicksonia sellowiana Hook. & 2 & 3 & 0 & 9.64 & 10.67 & 0.0665 & 0.0912 & 0 & 7.57 & 8.19 \\
\hline Eugenia pyriformis Cambess. & 2 & 2 & 0 & 0 & 0 & 0.0084 & 0.0088 & 0 & 1.35 & 1.37 \\
\hline Eugenia uniflora L. & 26 & 27 & 0 & 0.94 & 0.95 & 0.5701 & 0.5936 & 0.41 & 1.41 & 1.01 \\
\hline Eugenia uruguayensis Cambess. & 1 & 1 & 0 & 0 & 0 & 0.0218 & 0.0257 & 0 & 4.04 & 4.21 \\
\hline Guettarda uruguensis Cham. et Schltdl. & 2 & 2 & 0 & 0 & 0 & 0.0074 & 0.0065 & 5.60 & 2.41 & -3.27 \\
\hline Helietta apiculata Benth. & 5 & 5 & 0 & 0 & 0 & 0.3505 & 0.3777 & 0 & 1.85 & 1.89 \\
\hline Ilex theezans Mart. ex Reissek & 2 & 2 & 0 & 0 & 0 & 0.0149 & 0.0154 & 0 & 0.75 & 0.75 \\
\hline Inga virescens Benth. & 1 & 1 & 0 & 0 & 0 & 0.0034 & 0.0031 & 2.43 & 0 & -2.43 \\
\hline Lithrea brasiliensis Marchand & 11 & 11 & 0 & 0 & 0 & 0.7019 & 0.7713 & 0 & 2.33 & 2.39 \\
\hline Lonchocarpus campestris Mart. ex Benth. & 76 & 77 & 1.00 & 1.32 & 0.33 & 0.4417 & 0.4589 & 3.40 & 4.32 & 0.96 \\
\hline Luehea divaricata Mart. et Zucc. & 45 & 45 & 0 & 0 & 0 & 2.6559 & 3.0007 & $6 \times 10^{-4}$ & 3.01 & 3.10 \\
\hline Machaerium paraguariense Hassl. & 61 & 63 & 1.25 & 2.05 & 0.81 & 0.4758 & 0.5305 & 0.66 & 3.33 & 2.76 \\
\hline Matayba elaeagnoides Radlk. & 444 & 415 & 1.73 & 0.06 & -1.67 & 5.1934 & 5.4441 & 1.95 & 3.09 & 1.19 \\
\hline Maytenus aquifolia Mart. & 4 & 3 & 6.94 & 0 & -6.94 & 0.0103 & 0.0126 & 8.42 & 12.87 & 5.11 \\
\hline
\end{tabular}


Table 1 Continued

\begin{tabular}{|c|c|c|c|c|c|c|c|c|c|c|}
\hline $\begin{array}{l}\text { Myrceugenia cf. glaucescens (Cambess.) } \\
\text { D.Legrand et Kausel }\end{array}$ & 1 & 1 & 0 & 0 & 0 & 0.0286 & 0.0286 & 0 & 0 & 0 \\
\hline Myrcia oblongata DC. & 1 & 1 & 0 & 0 & 0 & 0.0020 & 0.0026 & 0 & 5.72 & 6.07 \\
\hline Myrcia splendens (Sw.) DC. & 1 & 1 & 0 & 0 & 0 & 0.0037 & 0.0035 & 1.17 & 0 & -1.17 \\
\hline $\begin{array}{l}\text { Myrcianthes gigantea (D. Legrand) D. } \\
\text { Legrand }\end{array}$ & 15 & 14 & 1.71 & 0 & -1.71 & 1.2757 & 1.3431 & 0.23 & 1.51 & 1.30 \\
\hline Myrcianthes pungens (O.Berg) D. Legrand & 21 & 21 & 1.21 & 1.21 & 0 & 0.8235 & 0.9463 & 1.39 & 4.76 & 3.54 \\
\hline Myrocarpus frondosus Allemão & 17 & 16 & 1.5 & 0 & -1.5 & 0.1779 & 0.1901 & 1.19 & 2.82 & 1.68 \\
\hline Myrsine coriacea (Sw.) R.Br. & 2 & 1 & 15.91 & 0 & -15.91 & 0.1328 & 0.1052 & 7.31 & 1.76 & -5.65 \\
\hline Nectandra lanceolata Nees & 3 & 3 & 0 & 0 & 0 & 0.3784 & 0.4293 & 0 & 3.10 & 3.20 \\
\hline Nectandra megapotamica (Spreng.) Mez & 117 & 112 & 1.09 & 0 & -1.09 & 5.5980 & 6.3525 & 0.89 & 3.98 & 3.21 \\
\hline NI & 5 & 5 & 0 & 0 & 0 & 0.1942 & 0.2090 & 0 & 1.82 & 1.85 \\
\hline Ocotea puberula (Rich.) Nees & 22 & 21 & 1.16 & 0 & -1.16 & 1.6987 & 1.8350 & 0.23 & 2.13 & 1.95 \\
\hline Ocotea pulchella (Nees) Mez & 7 & 7 & 0 & 0 & 0 & 0.3474 & 0.4063 & 0 & 3.84 & 3.99 \\
\hline Oreopanax fulvus Marchal & 2 & 2 & 0 & 0 & 0 & 0.0262 & 0.0315 & 0 & 4.49 & 4.70 \\
\hline Parapiptadenia rigida (Benth.) Brenan & 50 & 49 & 0.5 & 0 & -0.5 & 3.2426 & 3.7287 & 0.02 & 3.45 & 3.55 \\
\hline Phytolacca dioica $\mathrm{L}$. & 3 & 3 & 0 & 0 & 0 & 0.0396 & 0.0591 & 0 & 9.49 & 10.49 \\
\hline Pilocarpus pennatifolius Lem. & 54 & 49 & 3.93 & 1.57 & -2.40 & 0.3513 & 0.3519 & 2.91 & 2.95 & 0.04 \\
\hline Prunus myrtifolia (L.) Urb. & 5 & 5 & 0 & 0 & 0 & 0.3999 & 0.5093 & 0 & 5.86 & 6.23 \\
\hline Roupala montana Aubl. & 1 & 1 & 0 & 0 & 0 & 0.0585 & 0.0599 & 0 & 0.59 & 0.59 \\
\hline Schaefferia argentinensis Speg. & 3 & 3 & 0 & 0 & 0 & 0.0094 & 0.0116 & 0 & 4.98 & 5.24 \\
\hline Schinus lentiscifolius Marchand & 4 & 4 & 0 & 0 & 0 & 0.1943 & 0.2122 & 0.06 & 2.24 & 2.23 \\
\hline Scutia buxifolia Reissek & 1 & 0 & 100 & - & -100.00 & 0.0036 & 0 & 100.00 & - & -100.00 \\
\hline Sebastiania brasiliensis Spreng. & 218 & 195 & 3.63 & 0.91 & -2.75 & 1.4163 & 1.4703 & 3.49 & 4.39 & 0.94 \\
\hline $\begin{array}{l}\text { Sebastiania commersoniana (Baill.) L.B. } \\
\text { Sm. et Downs }\end{array}$ & 36 & 35 & 2.15 & 1.46 & -0.7 & 0.8635 & 0.7548 & 5.05 & 1.81 & -3.31 \\
\hline Sloanea monosperma Vell. & 2 & 2 & 0 & 0 & 0 & 0.0057 & 0.0073 & 0 & 5.76 & 6.11 \\
\hline Solanum pseudoquina A. St.-Hill. & 4 & 4 & 0 & 0 & 0 & 0.0733 & 0.0827 & 0 & 2.98 & 3.08 \\
\hline Solanum sanctaecatharinae Dunal & 1 & 1 & 0 & 0 & 0 & 0.0026 & 0.0048 & 0 & 13.81 & 16.02 \\
\hline Styrax leprosus Hook. et Arn. & 1 & 2 & 0 & 15.91 & 18.92 & 0.0127 & 0.0135 & 2.60 & 4.00 & 1.47 \\
\hline Syagrus romanzoffiana (Cham.) Glassman & 1 & 1 & 0 & 0 & 0 & 0.0718 & 0.0764 & 0 & 1.54 & 1.57 \\
\hline Xylosma tweediana (Clos) Eichler & 2 & 2 & 0 & 0 & 0 & 0.0164 & 0.0206 & 0 & 5.44 & 5.75 \\
\hline $\begin{array}{l}\text { Zanthoxylum kleinii (R.S.Cowan) } \\
\text { P.G.Waterman }\end{array}$ & 1 & 1 & 0 & 0 & 0 & 0.0058 & 0.0065 & 0 & 2.67 & 2.74 \\
\hline Zanthoxylum rhoifolium Lam. & 2 & 2 & 0 & 0 & 0 & 0.0172 & 0.0217 & 0 & 5.53 & 5.86 \\
\hline Zanthoxylum riedelianum Engl. & 2 & 2 & 0 & 0 & 0 & 0.0366 & 0.0401 & 0 & 2.30 & 2.35 \\
\hline Total of communities & 1,561 & 1,482 & 1.84 & 0.56 & -1.29 & 32.14 & 35.09 & 1.12 & 3.27 & 2.22 \\
\hline
\end{tabular}

have been more significant, since 1,561 individuals were inventoried in 2013 against 1,482 individuals inventoried in 2017 . Thus, the community has shown a mortality rate $\left(1.84 \%\right.$ year $\left.^{-1}\right)$ higher than the recruitment rate $(0.56 \%$ year $\left.^{-1}\right)$, resulting in a negative net change in the number of individuals $\left(-1.29 \%\right.$ year $\left.^{-1}\right)$.
While community has shown a reduction in the number of individuals, the contrary pattern was observed in the basal area, which increased from $32.14 \mathrm{~m}^{2} \mathrm{ha}^{-1}$ to $35.09 \mathrm{~m}^{2}$ $\mathrm{ha}^{-1}$ in 2017. Therefore, the basal area gain rate $(3.27 \%$ year $\left.{ }^{-1}\right)$ was higher than the loss rate $\left(1.12 \%\right.$ year $\left.^{-1}\right)$, resulting in a positive net change rate $\left(2.22 \%\right.$ year $\left.^{-1}\right)$. 
The botanical families Myrtaceae (11), Rutaceae (five), Fabaceae (five), Lauraceae (four) and Sapindaceae (four) have exhibited the highest species richness in both inventories. Of the 63 species initially sampled, 19 have shown a mortality rate higher than the recruitment rate; six species have shown a recruitment rate higher than the mortality rate; and 38 have kept a stable population - the set of five unidentified species has also kept a stable number of individuals. The three highest density species of the community (> 100 individuals), Matayba elaeagnoides Radlk., Nectandra megapotamica (Spreng.) Mez and Sebastiania brasiliensis Spreng., have followed the same loss pattern in individuals and obtained negative net change values $\left(-1.67 \%\right.$ year $^{-1},-1.09 \%$ year $^{-1}$ and $-2.75 \%$ year $^{-1}$, respectively). In all cases, despite the loss of individuals, surviving individuals have continued to growth so that the basal area gain rate was higher than the loss rate, resulting in a positive basal area net change for all three species $(1.19 \%$ year $^{-1}, 3.21 \%$ year $^{-1}$ and $0.94 \%$ year $^{-1}$, respectively) and confirming their good adaptation in the forest.

A high basal area gain rate has also been verified when considering all populations: 52 species have shown a positive net change in basal area, as well as the group of unidentified individuals; 10 species have shown a negative net change in basal area; and only one population has remained stable, therefore confirming the community pattern. In the case of species with reduced basal area, even with a stable population or gain in individuals (e.g. Guettarda uruguensis Cham. et Schltdl.), the pattern is especially explained by dead stems as many individuals are bifurcated and, sporadically, some of these bifurcations come to die.

Sectors have shown a pattern similar to what we have observed for the whole community, since all of them have shown a mortality rate higher than the recruitment rate and basal area gain rates higher than the loss rate (table 2). It should be noted that the Kruskal-Wallis test has indica- ted no significant differences among sectors according to the demographic rates (MR: $P=0.5854$; RR: $P=0.3501$; $\mathrm{NC}_{\mathrm{NI}}: P=0.6657$; LR: $P=0.0826$; GR: $P=0.6657 ; \mathrm{NC}_{\mathrm{BA}}$ : $P=0.5401)$.

By observing the demographic rates, by sector, of the 10 highest density populations in the forest, the high variation in the number of individuals of each population can be verified, therefore indicating their habitat preference and their variable performance in the sectors (table 3). For example, M. elaeagnoides has shown high density in the lower sector; in the intermediate sector, its participation has reached approximately only one-third of this value; and, in the upper sector, it has shown only one individual $(P<0.001)$. The species has shown individuals loss in the first two sectors, however, in both cases, including the only individual in the upper sector, there was growth and gain in basal area.

Sebastiania brasiliensis, showing opposite pattern in occupying the sectors, has shown the highest density in the upper sector; in the intermediate sector, the species density has reduced by half, reaching zero in the lower sector $(P<0.001)$. There was loss in number of individuals in the two sectors where it occurred, nonetheless the intermediate sector has shown a more expressive loss (almost 20 individuals). This has resulted in the basal area loss of this sector, unlike the upper sector where there was basal area gain with the growth of survivors in spite of losing individuals.

In addition, some distinct population patterns have stood out among sectors, for example, Lonchocarpus campestres Mart. ex Benth., a species that has shown smallsized individuals in the intermediate sector, which is expressed by the reduced values in basal area, has been found in larger size in the upper sector. In the intermediate sector, the 13 individuals initially sampled have made only $0.08 \mathrm{~m}^{2}$ $\mathrm{ha}^{-1}$ in basal area, while the two individuals in the upper sector have exceeded this value $\left(0.13 \mathrm{~m}^{2} \mathrm{ha}^{-1}\right)$, thus indi-

Table 2. Demographic rates by sector: lower sector (L), intermediate sector (I) and upper sector (U), with both the initial $\left(\mathrm{N}_{0}\right)$ and final $\left(\mathrm{N}_{1}\right)$ number of individuals, initial (BA $)$ and final $\left(\mathrm{BA}_{1}\right)$ basal area, mortality rate $(\mathrm{MR})$, recruitment rate (RR), basal area loss (LR) and gain $(\mathrm{GR})$ and net change in the number of individuals $\left(\mathrm{NC}_{\mathrm{NI}}\right)$ and in basal area $\left(\mathrm{NC}_{\mathrm{BA}}\right)$ for populations of a forest adjacent to the reservoir of a hydroelectric plant in the southern Brazilian Atlantic Forest. All rates are in \% year ${ }^{-1}$ and the basal area values are expressed in $\mathrm{m}^{2} \mathrm{ha}^{-1}$. Symbols beside demographic rates indicate significant $\left({ }^{*} P<0.05 ;{ }^{* *} P<0.01 ;{ }^{* * *} P<0.001\right.$; ${ }^{\text {ns }}=$ not significant $)$ comparisons of demographic rates among the reservoir distance sectors according to the Kruskal-Wallis test.

Tasas demográficas por sector inferior $(\mathrm{L})$, intermedio (I) y superior $(\mathrm{U})$, con número de individuos inicial $\left(\mathrm{N}_{0}\right)$ y final $\left(\mathrm{N}_{1}\right)$, área basal inicial $\left(\mathrm{BA}_{0}\right)$ y final $\left(\mathrm{BA}_{1}\right)$, tasas de mortalidad (MR), reclutamiento (RR), pérdida (LR) y ganancia (GR) en área basal y cambios líquidos en el número de individuos $\left(\mathrm{NC}_{\mathrm{NI}}\right)$ y en el área basal $\left(\mathrm{NC}_{\mathrm{BA}}\right)$ en un bosque adyacente al embalse de una central hidroeléctrica en la Mata Atlántica del sur de Brasil. Todas las tasas están en $\%$ año-1 y los valores de área basal están representados en $\mathrm{m}^{2} \mathrm{ha}^{-1}$. Los símbolos al lado de las tasas demográficas indican significancias estadísticas $\left({ }^{*} P<0,05 ; * * P<0,01 ; * * * P<0,001 ;\right.$ ns $=$ no significativo) en la comparación de las tasas demográficas entre los sectores de distintas distancias al embalse, según la prueba de Kruskal-Wallis.

\begin{tabular}{lcccccccccc}
\hline Sectors & $\mathrm{N}_{0}$ & $\mathrm{~N}_{1}$ & $\mathrm{MR}^{\mathrm{ns}}$ & $\mathrm{RR}^{\mathrm{ns}}$ & $\mathrm{NC}_{\mathrm{NI}}{ }^{\mathrm{ns}}$ & $\mathrm{BA}_{0}$ & $\mathrm{NA}_{1}$ & $\mathrm{LR}^{\mathrm{ns}}$ & $\mathrm{GR}^{\mathrm{ns}}$ & $\mathrm{NC}_{\mathrm{AB}}{ }^{\mathrm{ns}}$ \\
\hline Lower (L) & 573 & 559 & 1.24 & 0.63 & -0.62 & 11.22 & 12.59 & 0.87 & 3.69 & 2.92 \\
Intermediate (I) & 597 & 548 & 2.75 & 0.64 & -2.12 & 11.50 & 12.17 & 1.78 & 3.17 & 1.43 \\
Upper (U) & 391 & 375 & 1.37 & 0.34 & -1.04 & 9.43 & 10.33 & 0.62 & 2.88 & 2.32 \\
\hline
\end{tabular}


Table 3. Demographic rates for the 10 highest density populations considered in the sectors (St): lower (L), intermediate (I) and upper $(\mathrm{U})$, with both the initial $\left(\mathrm{N}_{0}\right)$ and final $\left(\mathrm{N}_{1}\right)$ number of individuals, initial $\left(\mathrm{BA}_{0}\right)$ and final $\left(\mathrm{BA}_{1}\right)$ basal area, mortality rate $(\mathrm{MR})$, recruitment rate (RR), basal area loss (LR) and gain (GR) and net change in the number of individuals $\left(\mathrm{NC}_{\mathrm{NI}}\right)$ and in basal area $\left(\mathrm{NC}_{\mathrm{BA}}\right)$ for populations of a forest adjacent to the reservoir of a hydroelectric plant in the southern Brazilian Atlantic Forest. All rates are in $\%$ year ${ }^{-1}$ and the basal area values are expressed in $\mathrm{m}^{2} \mathrm{ha}^{-1}$. The symbol $P$ in the columns indicates significant $\left({ }^{*} P<0.05 ;{ }^{* *} P<0.01 ;{ }^{* * *} P<0.001 ;{ }^{\text {ns }}\right.$ $=$ not significant) comparisons of the number of individuals and basal area between years according to t test $\left({ }^{\mathrm{t}}\right)$ or Mann-Whitney test $\left({ }^{\mathrm{m}}\right)$. The symbol $P$ in the lines $\left({ }^{*} P<0.05 ;{ }^{* *} P<0.01 ;{ }^{* * *} P<0.001 ;{ }^{\text {ns }}=\right.$ not significant $)$ comparisons of the number of individuals and basal area among sectors according to ANOVA $\left({ }^{\mathrm{A}}\right)$ or Kruskal-Wallis $\left({ }^{\mathrm{K}}\right)$. Values followed by distinct letters in the columns significantly differ from each other according to Tukey's tests (if ANOVA is performed) or non-parametric multiple comparisons (if Kruskal-Wallis is performed).

Tasas demográficas para las 10 poblaciones de mayor densidad, considerando los sectores (St) inferior (L), intermedio (I) y superior (U), con número de individuos inicial $\left(\mathrm{N}_{0}\right)$ y final $\left(\mathrm{N}_{1}\right)$, área basal inicial $\left(\mathrm{BA}_{0}\right)$ y final $\left(\mathrm{BA}_{1}\right)$, tasas de mortalidad $(\mathrm{MR})$, reclutamiento (RR), pérdida (LR) y ganancia $(\mathrm{GR})$ en área basal y cambios líquidos en el número de individuos $\left(\mathrm{NC}_{\mathrm{NI}}\right)$ y en el área basal $\left(\mathrm{NC}_{\mathrm{BA}}\right)$ en un bosque adyacente al embalse de una central hidroeléctrica en la Mata Atlántica del sur de Brasil. Todas las tasas están en $\%$ año $^{-1}$ y los valores de área basal están representados en $\mathrm{m}^{2}$ ha ${ }^{-1}$. Los símbolos de $P$ en cada columna indican significancias estadísticas $\left({ }^{*} P<0,05 ; * * P<0,01 ; * * * P<0,001\right.$; ns $=$ no significativo) en la comparación del número de individuos y del área basal entre los años, según la prueba $\mathrm{t}(\mathrm{t})$ o prueba de Mann-Whitney $(\mathrm{m})$. Los símbolos de $\mathrm{p}$ en las líneas $\left({ }^{*} P<\right.$ 0,$05 ; * * P<0,01 ; * * * P<0,001 ; \mathrm{ns}=$ no significativo) indican significancia estadística en la comparación del número de individuos y área basal entre los sectores, según ANDEVA (A) o Kruskal-Wallis (K). Letras diferentes en cada columna indican diferencias significativas, según la prueba de Tukey (con ANDEVA) o de contrastes múltiples no paramétrico (con Kruskal-Wallis).

\begin{tabular}{|c|c|c|c|c|c|c|c|c|c|c|c|c|c|}
\hline Species & $\mathrm{St}$ & $\mathrm{N}_{0}$ & $\mathrm{~N}_{1}$ & $P$ & MR & $\mathrm{RR}$ & $\mathrm{NC}_{\mathrm{NI}}$ & $\mathrm{BA}_{0}$ & $\mathrm{BA}_{1}$ & $P$ & LR & GR & $\mathrm{NC}_{\mathrm{AB}}$ \\
\hline \multirow{3}{*}{$\begin{array}{l}\text { Matayba } \\
\text { elaeagnoides }\end{array}$} & $\mathrm{L}$ & $327^{\mathrm{a}}$ & $306^{a}$ & ns-m & 1.73 & 0.08 & -1.65 & $4.10^{\mathrm{a}}$ & $4.30^{\mathrm{a}}$ & ns-t & 2.07 & 3.44 & 1.43 \\
\hline & I & $116^{\mathrm{b}}$ & $108^{b}$ & ns-m & 1.77 & 0 & -1.77 & $1.10^{\mathrm{a}}$ & $1.10^{\mathrm{a}}$ & ns-m & 1.53 & 1.62 & 1.09 \\
\hline & $\mathrm{U}$ & $1^{\mathrm{b}}$ & $1^{\mathrm{b}}$ & ns-m & 0 & 0 & 0 & $0.02^{\mathrm{b}}$ & $0.03^{b}$ & ns-m & 0 & 9.38 & 10.35 \\
\hline$P$ & & $* * * \mathrm{~K}$ & $* * * \mathrm{~K}$ & & & & & $* * * \mathrm{~K}$ & $* * * \mathrm{~K}$ & & & & \\
\hline \multirow{3}{*}{$\begin{array}{l}\text { Sebastiania } \\
\text { brasiliensis }\end{array}$} & $\mathrm{L}$ & $0^{\mathrm{b}}$ & $0^{\mathrm{b}}$ & ns-m & - & - & - & $0.00^{b}$ & $0.00^{\mathrm{b}}$ & ns-m & - & - & - \\
\hline & I & $93^{\mathrm{ab}}$ & $74^{\mathrm{ab}}$ & ns-m & 6.53 & 1.03 & -5.55 & $0.64^{\mathrm{ab}}$ & $0.62^{\mathrm{ab}}$ & ns-m & 5.27 & 4.68 & -0.62 \\
\hline & $\mathrm{U}$ & $125^{\mathrm{a}}$ & $121^{\mathrm{a}}$ & ns-t & 1.64 & 0.84 & -0.81 & $0.78^{\mathrm{a}}$ & $0.85^{\mathrm{a}}$ & ns-m & 2.12 & 4.19 & 2.16 \\
\hline$P$ & & $* * * \mathrm{~K}$ & $* * * \mathrm{~K}$ & & & & & $* * * \mathrm{~K}$ & $* * * \mathrm{~K}$ & & & & \\
\hline \multirow{3}{*}{$\begin{array}{l}\text { Nectandra } \\
\text { megapotamica }\end{array}$} & $\mathrm{L}$ & 25 & 24 & ns-m & 1.02 & 0 & -1.02 & 1.17 & 1.41 & ns-t & 0.46 & 5.12 & 4.91 \\
\hline & I & 53 & 50 & ns-m & 1.45 & 0 & -1.45 & 2.52 & 2.85 & ns-m & 0.90 & 3.94 & 3.17 \\
\hline & $\mathrm{U}$ & 39 & 38 & ns-m & 0.65 & 0 & -0.65 & 1.91 & 2.09 & ns-m & 1.16 & 3.27 & 2.19 \\
\hline$P$ & & ns-K & ns-K & & & & & ns-A & ns-A & & & & \\
\hline \multirow{3}{*}{$\begin{array}{l}\text { Lonchocarpus } \\
\text { campestris }\end{array}$} & $\mathrm{L}$ & $61^{a}$ & $63^{a}$ & ns-m & 0.83 & 1.63 & 0.81 & $0.24^{\mathrm{a}}$ & $0.28^{\mathrm{a}}$ & ns-m & 2.06 & 6.07 & 4.27 \\
\hline & I & $13^{\mathrm{ab}}$ & $12^{\mathrm{ab}}$ & ns-m & 1.98 & 0 & -1.98 & $0.08^{\mathrm{ab}}$ & $0.04^{\mathrm{ab}}$ & ns-m & 15.73 & 2.45 & -13.61 \\
\hline & $\mathrm{U}$ & $2^{\mathrm{b}}$ & $2^{\mathrm{b}}$ & ns-m & 0 & 0 & 0 & $0.13^{\mathrm{b}}$ & $0.13^{\mathrm{b}}$ & ns-m & 0 & 1.44 & 1.47 \\
\hline$P$ & & $* * * \mathrm{~K}$ & $* * * \mathrm{~K}$ & & & & & ${ }^{* * *} \mathrm{~K}$ & $* * * \mathrm{~K}$ & & & & \\
\hline \multirow{3}{*}{$\begin{array}{l}\text { Allophylus } \\
\text { edulis }\end{array}$} & If & $18^{\mathrm{a}}$ & $19^{\mathrm{a}}$ & ns-m & 0 & 1.34 & 1.36 & $0.09^{\mathrm{b}}$ & $0.10^{\mathrm{b}}$ & ns-m & 0 & 3.84 & 3.99 \\
\hline & It & $39^{a}$ & $37^{\mathrm{a}}$ & ns-m & 1.31 & 0 & -1.31 & $0.69^{\mathrm{a}}$ & $0.73^{\mathrm{a}}$ & ns-m & 1.07 & 2.73 & 1.71 \\
\hline & $\mathrm{S}$ & $9^{b}$ & $8^{b}$ & $\mathrm{~ns}-\mathrm{m}$ & 2.9 & 0 & -2.9 & $0.19^{\mathrm{b}}$ & $0.21^{\mathrm{b}}$ & ns-m & 0.68 & 2.69 & 2.06 \\
\hline$P$ & & ${ }^{* * \mathrm{~K}}$ & $* * \mathrm{~K}$ & & & & & ${ }^{* * \mathrm{~K}}$ & ${ }^{* * \mathrm{~K}}$ & & & & \\
\hline \multirow{3}{*}{$\begin{array}{l}\text { Campomanesia } \\
\text { xanthocarpa }\end{array}$} & If & $30^{\mathrm{a}}$ & $32^{\mathrm{a}}$ & ns-m & 0 & 1.6 & 1.63 & $0.24^{\mathrm{a}}$ & $0.29^{\mathrm{a}}$ & ns-m & 0.03 & 4.21 & 4.36 \\
\hline & It & $32^{\mathrm{ab}}$ & $33^{\mathrm{ab}}$ & ns-m & 0.79 & 1.55 & 0.77 & $0.57^{\mathrm{ab}}$ & $0.60^{\mathrm{ab}}$ & $\mathrm{ns}-\mathrm{m}$ & 1.63 & 2.98 & 1.39 \\
\hline & $\mathrm{S}$ & $4^{b}$ & $2^{\mathrm{b}}$ & ns-m & 15.91 & 0 & -15.91 & $0.37^{\mathrm{b}}$ & $0.40^{\mathrm{b}}$ & ns-m & 0.75 & 2.90 & 2.21 \\
\hline$P$ & & ${ }^{*} \mathrm{~K}$ & ${ }^{* *} \mathrm{~K}$ & & & & & $*_{\mathrm{K}}$ & ${ }^{*} \mathrm{~K}$ & & & & \\
\hline \multirow{3}{*}{$\begin{array}{l}\text { Cupania } \\
\text { vernalis }\end{array}$} & If & $9^{b}$ & 7 & ns-m & 6.09 & 0 & -6.09 & $0.13^{b}$ & $0.15^{\mathrm{b}}$ & ns-m & 2.35 & 6.96 & 4.95 \\
\hline & It & $33^{\mathrm{a}}$ & 31 & ns-m & 2.35 & 0.82 & -1.55 & $0.46^{\mathrm{ab}}$ & $0.43^{\mathrm{ab}}$ & ns-m & 3.50 & 2.10 & -1.43 \\
\hline & $\mathrm{S}$ & $21^{\mathrm{a}}$ & 19 & ns-m & 2.47 & 0 & -2.47 & $0.44^{\mathrm{a}}$ & $0.49^{\mathrm{a}}$ & ns-m & 0.76 & 3.63 & 2.98 \\
\hline$P$ & & ${ }^{*} \mathrm{~K}$ & ns-K & & & & & ${ }^{* \mathrm{~K}}$ & ${ }^{*} \mathrm{~K}$ & & & & \\
\hline
\end{tabular}


Table 3 Continued

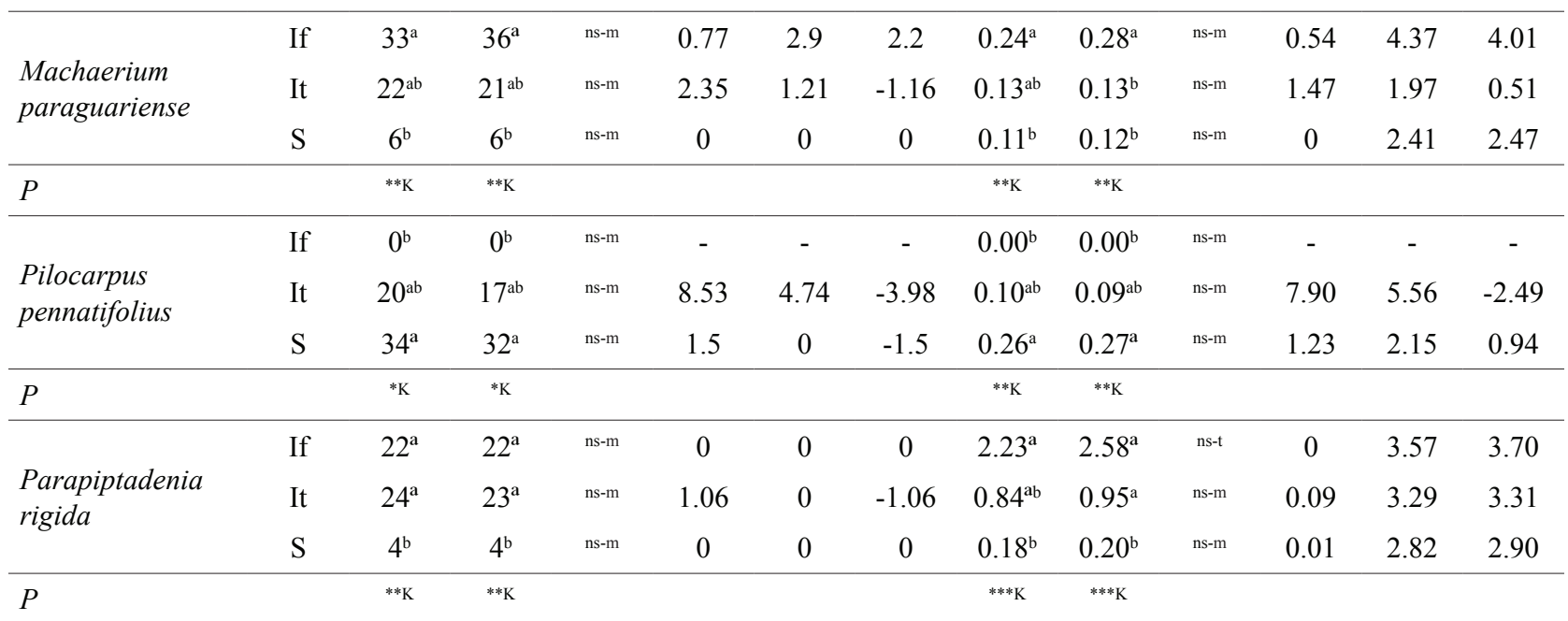

cating larger individuals. Similar pattern has occurred for Allophylus edulis (A.St.-Hil., Cambess. et A. Juss.) Radlk., however with the smallest individuals found in the lower sector. Campomanesia xanthocarpa O.Berg has stood out with few large-sized individuals in the upper sector, which has shown the highest basal area while the lower sector has shown the highest number of individuals.

\section{DISCUSSION}

In a four-year interval, the tree component dynamics pattern across the community and in each of the reservoir distance sectors was characterized by the species richness stability and structural development - expressed by the reduction in number of trees and the increase in basal area. Such pattern, which has already been observed in former studies carried out in this region (e.g., Lima 2016), is typical of areas in advanced stages of succession that have not undergone recent extreme environmental disturbances, as the area under study. It should be noted that the reduction in abundance along with the basal area gain is an indication that the forest is facing the self-thinning phase. This is a process dependent on trees density (Luo et al. 2012, Zhu et al. 2013), occurring when the forest reaches its maximum capacity to bear new tree individuals (Vospernik and Sterba 2015). Some trees are suppressed and die as a consequence of intense inter- and intra-specific competition, making room for the growth of the survivors (Vospernik and Sterba $2015)$. Yet the stability in the number of species indicates a low floristic turnover. The pattern we have observed was characterized by the high representativeness of Myrtaceae, just as reported by Nascimento et al. (2001) and Klauberg et al. (2010) for the Mixed Ombrophilous Forest, and by Jurinitz and Jarenkow (2003) for Seasonal Forest.

Considering the most abundant populations by sector, a structural variation according to their location can be noticed despite the general pattern of losing individuals and gaining basal area. Former studies carried out in the same area also indicated floristic-structural variations in the community related to the sectors location for both the adult (Souza et al. 2015) and the regenerative (Souza et al. 2017a) components. By investigating the functional aspects of the area under study, Souza et al. (2017b) likewise demonstrated that in the lower sector prevails a community with resources acquisition traits, however, in the slope intermediate and upper sectors conservative traits prevail. The sorting of tree species on account of the environmental gradient synthesized by relief variations is thus observed, reinforcing the importance of this ecological factor in local scale (Yang et al. 2014). Yet it is noteworthy that there was no evidence that this same environmental gradient has influenced the dynamics pattern of the most representative populations, since, in general, the loss of individuals and the gain in basal area have prevailed, just as observed for the community. In addition, the most abundant populations demographic rates have not been enough to result in their structural change over the study period. Perhaps, a longer period of observation may show more significant changes in the species patterns.

Besides the influence of stochastic events, the assembly of biological communities is substantially determined by the interaction between two ecological forces: environmental filters and limiting similarity (competition) (Cornwell and Ackerly 2009). In a tree species community, environmental filters are often reported as being of great importance in the early stages of succession; in later stages competition plays a more relevant role though (Lohbeck et al. 2014). Considering the predominant pattern of self-thinning and the absence of influence from the reservoir distance on the demographic rates, it is inferred that competition was more relevant than environmental filters on the forest dynamics of the area under study during the 
monitoring period. Indeed, density-dependent ecological factors, such as competition, have been reported to be of great relevance in forest ecosystems, by influencing not only species dynamics but also their patterns of abundance and richness (Volkov et al. 2005). About one decade after its filling, no influence of the Barra Grande Hydroelectric Plant water reservoir on tree component short-term dynamics (four years) was detected.

\section{CONCLUSIONS}

Given the demographic rates analysis, it is suggested that the forest is facing a phase of structural development. The loss of individuals, along with the gain in basal area, is related to a self-thinning process typical of advanced succession stage areas. Same results are observed by analyzing the highest density population dynamics and comparing three sectors. It is also concluded that, about 12 years after its filling, the tree component demographic rates of the adjacent forest are not being influenced by the Barra Grande Hydroelectric Power Plant reservoir. It is suggested that the main factor conditioning the forest dynamics is the competition among tree individuals, which is a density-dependent ecological process. Monitoring the area dynamics is critical for further inferences as well as observing a possible future change in species composition.

\section{ACKNOWLEDGEMENTS}

We thank CNPq for providing a research productivity grant to the tenth and eleventh authors of this paper and the land owner, Mr. Victor Hugo, for kindly allowing us to conduct the study on his property.

\section{REFERENCES}

APG IV (Angiosperm Phylogeny Group, US). 2016. An update of the Angiosperm Phylogeny Group classification for the orders and families of flowering plants: APG IV. Botanical Journal of the Linnean Society 181(1): 1-20.

Cornwell WK, DD Ackerly. 2009. Community assembly and shi$\mathrm{fts}$ in plant trait distributions across an environmental gradient in coastal California. Ecological Monographs 79(1): 109-126.

Gasper AL, A Uhlmann, L Sevegnani, DV Lingner, MJ RigonJúnior, M Verdi, A Stival-Santos, S Dreveck, M Sobral, AC Vibrans. 2013. Inventário florístico florestal de Santa Catarina: espécies da Floresta Estacional Decidual. Rodriguésia 64(3): 427-443.

Giraudoux P. 2017. pgirmess: Data Analysis in Ecology. R package version 1.6.7. Consulted 20 Oct. 2017. Available in https://CRAN.R-project.org/package=pgirmess.

Higuchi P, AT Oliveira-Filho, AC Silva, ELM Machado, RM Santos, DS Pifano. 2008. Dinâmica da comunidade arbórea em um fragmento de Floresta Estacional Semidecidual Montana em Lavras, Minas Gerais, em diferentes classes de solos. Revista Árvore 32(3): 417-426.

Higuchi P. 2017. forest.din: Função em linguagem de progra- mação estatística R para a determinação de taxas demográficas de espécies arbóreas. DOI: 10.5281/zenodo.439701. Consulted 20 Jun. 2017. Available in https:/github.com/ higuchip/forest.din.

IBGE (Instituto Brasileiro de Geografia e Estatística, BR). 2012. Manual Técnico da Vegetação Brasileira. Rio de Janeiro, Brazil. Instituto Brasileiro de Geografia e Estatística. 271 p.

Jurinitz CF, JA Jarenkow. 2003. Estrutura do componente arbóreo de uma floresta estacional na Serra do Sudeste, Rio Grande do Sul, Brasil. Brazilian Journal of Botany 26(4): 475-487.

Klauberg C, GF Paludo, RLC Bortoluzzi, A Mantovani. 2010. Florística e estrutura de um fragmento de Floresta Ombrófila Mista no Planalto Catarinense. Biotemas 23(1): 35-47.

Korning J, H Balslev. 1994. Growth and mortality of trees in Amazonian tropical rain forest in Ecuador. Journal of Vegetation Science 4(1): 77-86.

Lieberman D, M Lieberman, R Peralta, GS Hartshorn. 1985. Mortality patterns and stand turnover rates in a wet tropical forest in Costa Rica. Journal of Ecology 73(3): 915-924.

Lima CL. 2016. Impacto do reservatório de uma hidrelétrica sobre a vegetação arbórea em ecótono entre Floresta Ombrófila Mista e Floresta Estacional Decidual em Santa Catarina. Tesis Magíster em Ingeniero Forestal. Lages, Brazil. Universidade do Estado de Santa Catarina. 103 p.

Lohbeck M, L Poorter, M Martínez-Ramos, J Rodriguez-Velázquez, M Breugel, F Bongers. 2014. Changing drivers of species dominance during tropical forest succession. Functional Ecology 28(4): 1052-1058.

Luo Z, X Mi, X Chen, Z Ye, B Ding. 2012. Density dependence is not very prevalent in a heterogeneous subtropical forest. Oikos 121(8): 1239-1250.

Medeiros JD, M Savi, BFA Brito. 2005. Seleção de áreas para criação de Unidades de Conservação na Floresta Ombrófila Mista. Biotemas 18(2): 33-50.

Nascimento ART, SJ Longhi, DA Brena. 2001. Estrutura e padrões de distribuição espacial de espécies arbóreas em uma amostra de Floresta Ombrófila Mista em Nova Prata, RS. Ciência Florestal 11(1): 105-119.

Primack RB, PS Ashton, P Chai, HS Lee. 1985. Growth rates and population structure of Moraceae trees in Sarawak, East Malaysia. Ecology 66(2): 577-588.

R Development Core Team. 2017. R: A language and environment for statistical computing. R Foundation for Statistical Computing. Consulted 20 May. 2017. Availabe in http:// www.r-project.org/.

Ruschel AR, ES Nodari, MP Guerra, RO Nodari. 2003. Evolução do uso e valorização das espécies madeiráveis da Floresta Estacional Decidual do Alto-Uruguai, SC. Ciência Florestal 13(1): 153-166.

Sheil D, RM May. 1996. Mortality and recruitment rate evaluations in heterogeneous tropical forests. Journal of Ecology 84(1): 91-100.

SOS Mata Atlântica. 2012. Relatório de Atividades 2011. São Paulo, Brazil. SOS Mata Atlântica. 58 p.

Souza K, CC Souza, MG Rosa, AP Cruz, CL Lima, JO Silva, LC Lazzarin, R Loebens, RAR Dias, AC Silva, P Higuchi, MB Schimalski. 2015. Estrutura e estratégias de dispersão do componente arbóreo de uma floresta subtropical ao longo de uma topossequência no Alto-Uruguai. Scientia Forestalis 43(106): 321-332. 
Souza CC, P Higuchi, AC Silva, K Souza, A Dalla Rosa, CCC Rech, LC Rodrigues Junior, FF Walter. 2017a. FloristicStructural variation of natural regeneration along different topographic positions of an ecotonal forest in Santa Catarina, Brazil. Revista Árvore 41(3): e410305.

Souza K, P Higuchi, AC Silva, MB Schimalski, R Loebens, F Buzzi Junior, CC Souza, LC Rodrigues Junior, FF Walter, FF Missio, A Dalla Rosa. 2017b. Partição de nicho por grupos funcionais de espécies arbóreas em uma floresta subtropical. Rodriguésia 68(4): 1165-1175.

Vibrans AC, L Sevegnani, AL Gasper, DV Lingner. 2013. Inventário Florístico Florestal de Santa Catarina. Volume III: Floresta Ombrófila Mista. Blumenau, Brazil. Edifurb. $448 \mathrm{p}$.
Volkov I, JR Banavar, F He, SP Hubbell, A Maritan. 2005. Density dependence explains tree species abundance and diversity in tropical forests. Nature 438(7068): 658-661.

Vospernik S, H Sterba. 2015. Do competition-density rule and self-thinning rule agree? Annals of Forest Science 72(3): 379-390.

Yang J, X Ci, M Lu, G Zhang, M Cao, J Li, L Lin. 2014. Functional traits of tree species with phylogenetic signal co-vary with environmental niches in two large forest dynamics plots. Journal of Plant Ecology 7(2): 115-125.

Zhu Y, S Getzin, T Wiegand, H Ren, K Ma. 2013. The relative importance of Janzen-Connell effects in influencing the spatial patterns at the Gutianshan subtropical forest. PloS one 8(9): e74560.

Recibido:12/11/17

Aceptado: 14/05/18 